\title{
Reclaimed Water as an Alternative Water Source for Crop Irrigation
}

\author{
Lawrence R. Parsons ${ }^{1}$ \\ University of Florida, IFAS, Horticultural Sciences Department, Citrus Research and Education Center, \\ 700 Experiment Station Road, Lake Alfred, FL 33850
}

Bahman Sheikh

Bahman Sheikh Associates, 3524 22nd Street, San Francisco, CA 94114

Robert Holden

Monterey Regional Water Pollution Control Agency, 5 Harris Court, Building D, Monterey, CA 93940

David W. York

York Water Circle, 3158 S. Fulmer Circle, Tallahassee, FL 32303

Additional index words. recycled water, reclaimed water, irrigation, reuse, wastewater, citrus

\begin{abstract}
Reclaimed water has been safely and successfully used for more than 40 years in Florida and California. Reclaimed water in these states is regulated with restrictions more stringent than World Health Organization guidelines. In the United States, Florida is currently the largest producer and California is the second largest producer of reclaimed water. Reclaimed water is more highly tested than other sources of irrigation water, and the safety of this water has been demonstrated in these and other states. Very high application rates of reclaimed water to citrus on well-drained Florida sands increased tree growth and fruit production. Although reclaimed water contains some nutrient elements, there is usually insufficient macronutrient content to meet plant nutritional requirements. Most reclaimed waters do not have high salinity levels although they are slightly more salty than the potable waters from which they originated. With an adequate leaching fraction, salts in reclaimed water can be handled with appropriate irrigation management. Use of reclaimed water has steadily increased in Florida since 1992, but other entities besides agricultural irrigation are now competing for its use. Public acceptance of reclaimed water has also increased, and crops grown with reclaimed water in Florida and California have been marketed without a negative public reaction. Recent issues of food safety have caused some to question reclaimed water, but there is no evidence of food safety problems with its use. Although reclaimed water in Florida was initially promoted as a way to improve surface water quality, it has now become an important alternate source of water to help meet water shortages and urban demand. In California, reclaimed water has become a necessary part of statewide water management.
\end{abstract}

The purpose of this article is to discuss several aspects of reclaimed water that are of importance today. Emphasis is placed on water reuse in Florida and California because they are two of the largest producers of reclaimed water in the United States. The term "reclaimed water" is commonly used in Florida. California changed from "reclaimed water" to "recycled water" in 2000 (State of California, 2000). For the purpose of this discussion, both terms are considered to mean the same thing. Reclaimed water in Florida is defined as "water that has received at least secondary treatment and basic disinfection and is reused after flowing out of a domestic wastewater treatment facility" [Florida Department of Environmental Protection (FDEP), 2010c].

Florida has less than half the population of California. Statewide, Florida receives an average of $1372 \mathrm{~mm}$ of rainfall annually (FDEP, 2010b), whereas much of southern California receives less than half that amount, yet Florida is the leading state in the nation in

Received for publication 20 Jan. 2010. Accepted for publication 7 May 2010

Part of a colloquium (The Efficient Use of Alternative Water and Traditional Irrigation Sources in Horticulture) presented 25 July 2009 at ASHS-2009, St. Louis, MO; sponsored by the Water Utilization and Management (WUM) Working Group.

${ }^{1}$ To whom reprint requests should be addressed; e-mail1rp@crec.ifas.ufl.edu. terms of reclaimed water production. Why is this?

Issues relating to water quality, population growth, environmental regulations, and saltwater intrusion are some of the primary reasons that Florida currently produces more reclaimed water than other states. Florida's population increased fivefold from 1950 to 2000 , and it is now the fourth largest state in the nation with a 2009 estimated population of 18.5 million (U.S. Census Bureau, 2010).

Several major reclaimed water projects in Florida were started for water quality reasons. The city of St. Petersburg brought its reclaimed water system online in 1977 after passage of the Wilson-Grizzle Act (Asano et al., 2007). This act mandated that "wastewater treatment plants discharging to Tampa Bay and its tributaries treat their wastewater to that of drinking water standards..." (Tchobanoglous et al., 2003). St. Petersburg became the first major city in the United States to reach zero discharge of wastewater effluent into nearby surface waters. By using reclaimed water instead of groundwater, this project reduced demand for well water near the coast and thus helped slow saltwater intrusion. Another project, Water Conserv II, was started in 1986 to stop discharge of treated wastewater from Orlando and Orange County into Lake Tohopekaliga, an important recreational bass fishing lake (Parsons, 2009). Now, water shortages (or water quantity issues) in Florida are helping drive the increased production of reclaimed water.

Recent spring droughts from 2000 through 2009 in Florida increased demand for reclaimed water. Severe restrictions were placed on residential irrigation with potable water, but fewer restrictions were placed on reclaimed water irrigation. The Water Management Districts in Florida are actively promoting the use of reclaimed water as a way to reduce potable water use (Southwest Florida Water Management District, 2009a, 2009b).

With less rainfall and a larger population than Florida, California also has strong reasons for reclaiming water. Currently, California uses nearly half of its reclaimed water on agriculture and the rest on landscape irrigation and other uses. The two largest reclaimed water projects for food crop irrigation in California (and the United States) were developed in response to seawater intrusion. The Monterey County Water Recycling Projects (Asano et al., 2007) irrigates over 4800 ha with over 18.8 billion liters per year of reclaimed water. Crops grown include artichokes (Cynara cardunculus), lettuce (Lactuca sativa), strawberries (Fragaria ×ananassa), celery (Apium graveolens), cauliflower (Brassica oleracea), broccoli (Brassica oleracea), and spinach (Spinacia oleracea). The Watsonville Area Water Recycling Project irrigates over 800 ha of similar crops with over 4.9 billion liters per year of reclaimed water (Pajaro Valley Water 
Management Agency, 2010). The Irvine Ranch Water District has been providing reclaimed water for irrigation of over 400 ha of food crops for over 40 years (Irvine Ranch Water District, 2010). Their crops include lettuce and strawberries. The city of Santa Rosa has used reclaimed water for grapes (Vitis vinifera), row crops, and fodder for over 32 years. Currently, they use 6.8 billion liters per year to irrigate 2300 ha (Piazza, 2010). These and other California projects also produce organic certified crops with reclaimed water.

\section{USES OF RECLAIMED WATER}

As of 2008, Florida produced an estimated 921.3 billion liters per year of reclaimed water (FDEP, 2010a). California is gathering data for a survey of reclaimed water use, which they anticipate completing in 2010. The only accurate statewide survey was conducted for 2001 production and published in 2002. In 2001, California's production was 648 billion liters per year (California EPA, 2002; Water Facts, 2004).

In 1992, Florida produced 1.098 billion liters of reclaimed water per day and this more than doubled to 2.524 billion liters per day by 2008 (FDEP, 2010a). In 1992, agriculture was the largest user of reclaimed water in Florida and golf course irrigation was the second largest user. By 2008, Florida agriculture used only $12 \%$, whereas golf courses used $19 \%$ of the total reclaimed water (Fig. 1). In contrast,

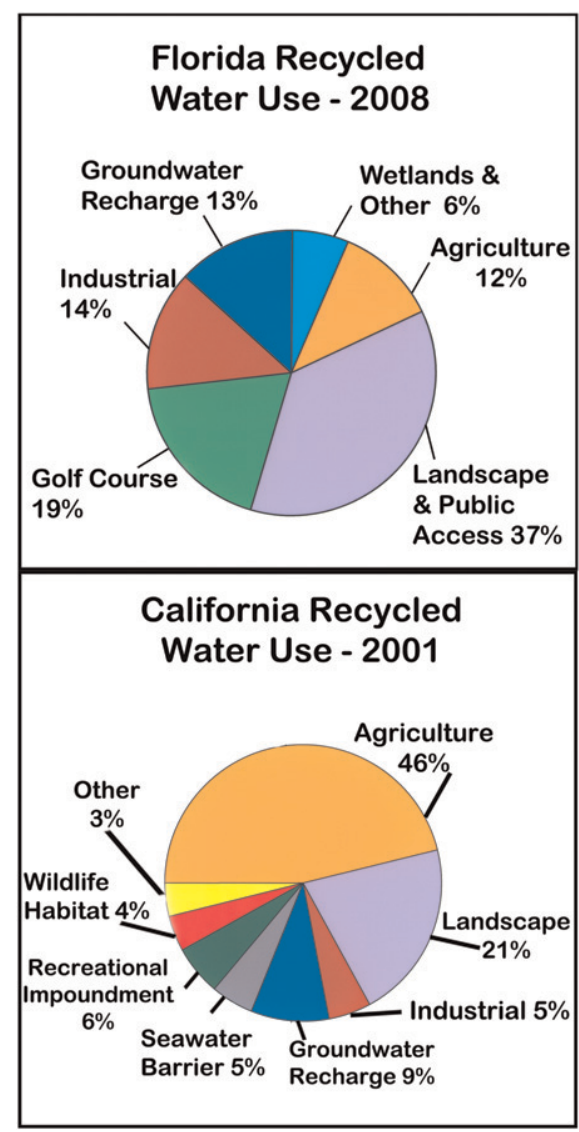

Fig. 1. Water reuse in Florida and California. agriculture was still the dominant user of reclaimed water in 2001 in California (Fig. 1) and accounted for $46 \%$ of the total reclaimed water use, whereas golf courses and landscaping accounted for $21 \%$. Of the new reclaimed water projects since 2001, 84\% convert wastewater into water that percolates into the drinking water groundwater system [e.g. Orange County's Groundwater Replenishment Project (96.7 billion liters per year)].

The U.S. Environmental Protection Agency (EPA) established guidelines for water reuse. Rather than establishing national water reuse standards, the EPA decided that comprehensive federal guidelines, along with state regulations, would increase implementation of water reuse projects. Hence, states have established their own water reuse regulations. In Florida, the FDEP established water quality standards and regulates reclaimed water. In California, the predecessor of the California Department of Public Health established the first criteria for crop irrigation with reclaimed water in 1918 (Crook, 2002). The modern era regulations were established in 1968 and have been revised three times since then.

\section{SAFETY OF RECLAIMED WATER}

Reclaimed water has an excellent safety record. Reclaimed water has been used in Florida for more than 40 years with no reported incidence of human illness (Southwest Florida Water Management District, 2009b). In Florida, reclaimed water is water that has received at least secondary treatment and basic disinfection. Because it is disinfected (usually by chlorination), reclaimed water can be better than some other irrigation sources from a health and safety point of view. In fact, reclaimed water undergoes more testing than most irrigation waters. Water quality standards for reclaimed water are stricter than standards for recreational water. Because of these strict water quality standards, there is essentially no risk to humans or animals from periodic contact with reclaimed water.

Reclaimed water can meet drinking water standards for many elements, but reclaimed water is not required to meet all the drinking water standards. Reclaimed water is not currently intended to be directly used for drinking. However, indirect potable reuse has become more common, particularly in California (Asano et al., 2007).

The National Research Council (1996) concluded, "Where reclaimed water has been used for food crop production, the state standards for wastewater treatment and reuse, along with site restrictions and generally good system reliability, have insured that food crops thus produced do not present a greater risk to the consumer than do crops irrigated from conventional sources."

\section{IRRIGATION OF EDIBLE CROPS}

For crops in Florida that are "peeled, cooked, or thermally processed," reclaimed water can be directly applied to the edible part of the crop. Hence, reclaimed water can be used with overhead irrigation for citrus and other crops that are peeled or cooked.

For crops that are eaten raw (called the "salad crops"), FDEP regulations currently require that there be no direct contact of the reclaimed water with the edible part of the crop. This means that growers of salad crops who irrigate with reclaimed water should use drip, bubbler, or furrow irrigation, which does not spray water directly on the crop. This regulation also means that reclaimed water cannot be used in Florida for overhead frost protection sprays onto crops such as blueberries or strawberries (Parsons, 2009).

The regulation prohibiting direct contact of reclaimed water with salad crops was created in the 1980s to encourage acceptance of reclaimed water in Florida. At the time, there were not sufficient studies to determine whether such a precaution was necessary. Since then, studies conducted in California (Engineering Science, 1987; Sheikh et al., 1990) have shown that salad crops can be directly sprayed with reclaimed water with no health, safety, or marketing problems. This finding was expected because reclaimed water is disinfected, usually by chlorination. Reclaimed water has been successfully sprayed onto the edible portion of salad crops and strawberries for over 40 years in California. Nationally, there has never been a documented case of human illness caused by reclaimed water (Crook, 2002).

\section{NUTRIENTS IN RECLAIMED WATER}

Most wastewater treatment facilities do not monitor nutrients in detail. However, one facility that has regularly monitored nutrients and other elements is the Water Conserv II project near Orlando, FL. Maximum average concentration limits and typical concentrations of elements in this reclaimed water are shown in Parsons et al. (2001b). Nutrient concentration in reclaimed water, particularly advanced treated reclaimed water, is usually low. Important macronutrients include nitrogen $(\mathrm{N})$, phosphorus $(\mathrm{P})$, potassium $(\mathrm{K})$, calcium $(\mathrm{Ca})$, and magnesium. For example, the typical concentration of total $\mathrm{N}$ in reclaimed water with biological nutrient removal is 2 to $12 \mathrm{mg} \cdot \mathrm{L}^{-1}$ (Asano et al., 2007) For advanced wastewater treatment in Florida, total $\mathrm{N}$ cannot exceed $3 \mathrm{mg} \cdot \mathrm{L}^{-1}$ (Florida Statutes, 2010). Reclaimed water can also contain low levels of other essential elements such as manganese, zinc, and boron (B) Boron is an element that is essential for plant growth in small quantities, but it can cause plant damage if too much is applied (Asano et al., 2007).

Along with other environmental factors, the amount of nutrient uptake from reclaimed water by plants depends on the concentration of nutrients, amount of reclaimed water applied, and residence time of the reclaimed water in the root zone. With regular irrigation, several turfgrasses can extract some $\mathrm{N}$ and $\mathrm{P}$ from reclaimed water. In those cases, reclaimed water can supply a reasonable amount of these nutrients. With other crops such as citrus, 
normal irrigation with reclaimed water provides less than $16 \%$ of the $\mathrm{N}$ requirement for mature trees. Although reclaimed water can provide some essential elements, the concentrations of $\mathrm{N}$ and $\mathrm{K}$ are usually too low to meet plant needs completely. Hence, additional applications of $\mathrm{N}, \mathrm{K}$, and other fertilizer elements are necessary to ensure good plant growth.

\section{SALINITY AND SODICITY}

Water quality of recycled waters may impact plants, soils, and irrigation systems. Most recycled waters do not inherently contain higher concentrations of salts although they typically contain $\approx 150$ to $400 \mathrm{mg} \cdot \mathrm{L}^{-1}$ more total dissolved solids than the potable waters from which they originated (Asano et al., 1984). In coastal areas, the incoming water source used to produce reclaimed water may already be salty. Also, the pipes carrying groundwater to the wastewater treatment facility may pass through areas of salty water. If salty water infiltrates into the incoming water pipes, the level of salt in the reclaimed water can further increase. If communities use sodium chloride $(\mathrm{NaCl})$-based water softeners, the reclaimed water may contain elevated $\mathrm{Na}$ and $\mathrm{Cl}$ ions compared with the potable water supply. Use of cleaning agents such as detergents may also elevate B concentrations in recycled waters. Many water reclamation facilities monitor salts (i.e., chlorides). If the salt concentration gets too high (more than 350 to $400 \mathrm{mg} \cdot \mathrm{L}^{-1}$ ), they will typically divert the salty reclaimed water to another discharge point.

Plants have a wide range of tolerance to salinity, and many of them can be irrigated with recycled water without impact. Sensitive plants typically exhibit foliar leaf damage, slower growth, and, in more severe cases, defoliation and death. Excessive levels of $\mathrm{Na}$ may also cause an imbalance in mineral nutrition of plants such as Ca deficiency. The presence of dissolved mineral salts has an osmotic effect on plants, and some constituents like $\mathrm{Na}, \mathrm{Cl}$, and $\mathrm{B}$ cause specific ion toxicities to plants (Hanson et al., 1993).

Salts have a tendency to build up on the root zone of actively transpiring plants because more or less pure water is lost to the atmosphere through evaporation and transpiration, whereas dissolved mineral salts in the applied water are left behind in the soil solution. It is necessary to maintain a salt balance in the root zone to obtain satisfactory plant performance, especially under semiarid climatic conditions when natural rainfall may be insufficient to leach salts out of the root zone. In surfaceirrigated soils (e.g., sprinklers) with no drainage impediments, the upper root zone is the zone of salt leaching, whereas the lower root zone is the zone of salt accumulation.

In inland Florida locations, salt in reclaimed water is not usually a problem. However, in coastal regions, whether the result of infiltration into the incoming water source or naturally high levels of $\mathrm{Na}$ and $\mathrm{Cl}$, salts in reclaimed water can sometimes be a problem for salt-sensitive plants such as azaleas (Rhododendron sp.) or Chinese privet (Ligustrum sinense). If salinity is too high, the reclaimed water may be acceptable for some lawn irrigation but not for irrigation of salt-sensitive plants.

In California, the most common saltsensitive crops are avocadoes (Persea americana), strawberries, and lettuce (Asano et al., 2007). All are grown with reclaimed water, but some actions may be necessary on the grower's part to be successful. Some municipalities have been successful in reducing brines and salts from entering the sewage system and thus reducing the salt in the reclaimed water. Other municipalities have encouraged the use of $\mathrm{KCl}$ rather than $\mathrm{NaCl}$ in residential and commercial water softeners to reduce $\mathrm{Na}$ while increasing $\mathrm{K}$ (a plant nutrient).

Soil permeability is affected by the combined effects of sodicity and salinity in the applied water. Sodicity is usually evaluated by the sodium adsorption ratio (SAR), a ratio of sodium to calcium plus magnesium, and salinity by electrical conductivity (EC). A moderate level of SAR and low EC may result in reduced soil permeability of some soil types. In contrast, the detrimental effects of moderate levels of SAR on soil permeability may be partially overcome by moderate levels of EC. In some treatment processes for recycled waters, additives are used that elevate SAR (e.g., using sodium hypochlorite for disinfection) and/or bicarbonate and carbonate concentrations (e.g., using lime to neutralize water $\mathrm{pH}$ ). Nearly all recycled waters produced in California have a combination of salinity and sodicity that puts them in the safe range in terms of impacts on soil permeability.

A second sodicity parameter known as residual sodium carbonate, the difference between the sum of bicarbonate and carbonate ions minus sodium ion, is used to evaluate detrimental effects that cause dispersal of soil organic matter resulting, for instance, in dark unsightly matting on turf in golf courses and reduced water infiltration rates into turf soils.

Another constituent of concern in recycled waters is excessive $\mathrm{N}$ in the form of dissolved ammonia or ammonium ions and nitrates. The presence of these forms of $\mathrm{N}$ is highly dependent on the wastewater treatment processes used. Ammonia or ammonium ions in applied waters are eventually oxidized to nitrate ions in the soil. Nitrogen in recycled water used for irrigation can be an issue because nitrates not taken up by plant roots may run off or leach below the root zone. This can contribute to nitrate contamination of surface waters or underlying groundwater basins. Nitrate leaching losses may be minimized if $\mathrm{N}$ content in the recycled water is taken into account as contributing to the $\mathrm{N}$ requirement of plants.

Fortunately, most landscape plants have a denser rooting system in the surface depths where soil salinity tends to be lowest. Soil water is extracted from the more saline deeper root zone only when the available soil water becomes limiting in the less saline portions. The extent of accumulation of salts in the lower root zone is regulated by the leaching fraction (LF), the ratio of depth of drainage water to depth of applied water. The depth of drainage water may be obtained from the difference between applied water and water lost to the atmosphere from transpiration by plants and surface soil evaporation. In freely draining soils, a comparatively small depth of drainage may be sufficient to keep the root zone in salt balance. A LF of 0.15 to 0.2 is usually adequate to maintain salt balance for irrigation of most plant species and for typical recycled water salinities (Hanson et al., 1993).

\section{PERCEPTION OF RECLAIMED WATER}

When the idea of using reclaimed water for irrigation was first presented to Florida citrus growers for the Water Conserv II project in the 1980s, they initially rejected using such water as a result of concerns about tree damage by heavy metals, salinity, disease organisms, or excessive water (Parsons et al., 2001a). After much negotiation, water quality standards were established, and several growers decided to take a chance with the reclaimed water. At the request of growers, research was carried out on this water by scientists at the University of Florida (Parsons et al., 2001a). The research showed that very high quantities of this water could be applied to citrus on well-drained soils with no negative effects (Parsons et al., 2001b). Tree growth and fruit production were greater at rates of $2500 \mathrm{~mm} /$ year than at lower irrigation rates. Although the concentration of juice soluble solids in the fruit was lowered by the high irrigation rate, total soluble solids per hectare were significantly higher as a result of the greater fruit production caused by the greater tree canopy growth.

Water quality standards were maintained, and more growers agreed to accept reclaimed water. Now, citrus growers who initially opposed the use of reclaimed water are enthusiastic supporters of this water. In addition, over 800 parks and 477 golf courses are currently irrigated with reclaimed water (FDEP, 2010a). With fewer irrigation restrictions on reclaimed water during droughts, public acceptance has also increased noticeably.

However, perception issues still exist. For example, many Florida tomato growers do not want to use reclaimed water because of perceived, but scientifically unfounded, concerns over food safety. This attitude developed because Florida tomato growers were economically hurt by a Salmonella incident (Sutton, 2008). Because of a Salmonella outbreak in 2008, the U.S. Food and Drug Administration initially recommended that people not eat certain types of raw tomatoes. It was later found that tomatoes were not the source of Salmonella, but Florida growers lost an estimated $\$ 50$ to $\$ 100$ million because of the negative publicity. Although reclaimed water has no association with Salmonella, Florida tomato growers are reluctant to use it because of perceived issues related to food safety. 
In California, the 2006 spinach Escherichia coli $\mathrm{O} 157: \mathrm{H} 7$ incident devastated fresh spinach sales for over a year (U.S. Department of Agriculture Economic Research Service, 2010). Although reclaimed water was not the source or involved in transport of the pathogen, there was an outcry against the use of reclaimed water for food crops. A result of that incident was the California Leafy Green Marketing Agreement (LGMA, 2009). This is a set of best practices developed by the growers and accepted by the state. The bacterial restrictions on irrigation water in that agreement are considerably less stringent than those imposed by Florida or California although more stringent than the World Health Organization's guidelines. All the major shippers and buyers have accepted the LGMA and demand that their growers follow the agreement. As a result, more growers have been asking their water providers for reclaimed water because it easily meets the LGMA irrigation water requirements.

\section{CONCLUSIONS}

Reclaimed water use has increased steadily since the 1980s, and Florida is now the largest producer of this water in the United States. This water has an excellent safety record and has been used successfully for more than 40 years. Although reclaimed water in Florida was initially promoted to improve surface water quality, it has now become an important alternate source of water to help meet water shortages and urban demand. In California, reclaimed water has become a necessary piece of the whole water picture and is increasingly becoming an indirect source for drinking water.

\section{Literature Cited}

Asano, T., F.L. Burton, H.L. Leverenz, R. Tsuchihashi, and G. Tchobanoglous. 2007. Water reuse: Issues, technologies, and applications. Metcalf \& Eddy. McGraw Hill, New York, NY.

Asano, T., R.G. Smith, and G. Tchobanoglous. 1984. Municipal wastewater: Treatment and reclaimed water characteristics, p. 1-26. In:
Pettygrove, G.S. and T. Asano (eds.). Irrigation with Reclaimed Municipal Wastewater - A Guidance Manual. Report No. 84-1 wr, Calif. State Water Resources Control Board, Sacramento, CA.

California, E.P.A. 2002. Municipal wastewater recycling survey. 19 July 2010 . <http://www. waterboards.ca.gov/water_issues/programs/ grants_loans/water_recycling/munirec.shtml $>$.

Crook, J. 2002. The ongoing evolution of water reuse criteria. In: Proc. of the AWWA/WEF 2002 Water Sources Conference (CD-ROM), 27-30 Jan. 2002, Las Vegas, NV.

Engineering Science. 1987. Monterey Wastewater Reclamation Study for Agriculture final report. 20 July 2010. <http://www.mrwpca.org/dwnloads/ wr/mwrsa.pdf $>$.

Florida Department of Environmental Protection. 2010a. 2008 Reuse inventory. 20 July 2010 $<$ http://www.dep.state.fl.us/water/reuse/docs/ inventory/2008_reuse-report.pdf>.

Florida Department of Environmental Protection. 2010b. Frequently asked questions. 20 July 2010. $<$ http://www.dep.state.fl.us/Drought/faq. $\mathrm{htm} \# 01>$.

Florida Department of Environmental Protection. 2010c. Reuse facts. 20 July 2010 . $<$ http://www. dep.state.fl.us/Water/Reuse/facts.htm>.

Florida Statutes. 2010. Chapter 403. 20 July 2010. $<$ http://www.leg.state.fl.us/statutes/index.cfm? App_mode=Display_Statute\&Search_String= \&URL $=0400-0499 / 0403 /$ Sections $/ 0403.086$. html>.

Hanson, B., S.R. Grattan, and A. Fulton. 1993. Agricultural salinity and drainage. University of California Irrigation Program, University of California, Davis, CA.

Irvine Ranch Water District. 2010. Recycling. Agricultural irrigation. 20 July 2010. <http:// www.irwd.com/Reclamation/reclaimed_usage. php>.

LGMA. 2009. Commodity specific food safety guidelines for the production and harvest of lettuce and leafy greens. 10 July 2009. 27 July 2010. <http://www.caleafygreens.ca.gov/trade/ documents/LGMAAcceptedGAPs07.10.09. pdf>.

National Research Council. 1996. Use of reclaimed water and sludge in food crop production. National Academics Press, 20 July 2010. <http:// books.nap.edu/openbook.php?record_id $=5175 \&$ page $=3>$.

Pajaro Valley Water Management Agency. 2010. Recycled water frequently asked questions.
20 July 2010. <http://www.pvwma.dst.ca.us/ project_operations/recycled_water.shtml $>$.

Parsons, L.R. 2009. Reclaimed water for homeowner irrigation. University of Florida EDIS. 20 July 2010 . <http://edis.ifas.ufl.edu/hs1157>.

Parsons, L.R., K.T. Morgan, T.A. Wheaton, and W.S. Castle. 2001a. Wastewater and reclaimed water-Disposal problem or potential resource? Proc. Fla. State Hort. Soc. 114:97100.

Parsons, L.R., T.A. Wheaton, and W.S. Castle. 2001b. High application rates of reclaimed water benefit citrus tree growth and fruit production. HortScience 36:1273-1277.

Piazza, R. 2010. Phone conversation with Robert Holden. 18 Mar. 2010.

Sheikh, B., R.P. Cort, W.R. Kirkpatrick, R.S. Jaques, and T. Asano. 1990. Monterey wastewater reclamation study for agriculture. J. Water Pollut. Control Fed. 62:216-226.

Southwest Florida Water Management District. 2009a. Reclaimed water. 19 July 2010. <http:// www.swfwmd.state.fl.us/conservation/reclaimed/>.

Southwest Florida Water Management District. 2009b. Reclaimed water: A reliable, safe alternative water supply. 19 July $2010 .<$ http:// www.swfwmd.state.fl.us/files/database/site file_sets/118/reclaimed_water_lev2_08.09. pdf $>$.

State of California. 2000. Water recycling criteria. California Code of Regulations, Title 22, Division 4, Chapter 3. California Department of Health Services, Sacramento, CA.

Sutton, J. 2008. North American tomato industry reeling: Growers. Reuters. 19 July 2010. <http:// www.reuters.com/article/idUSN6A33595920 080610>.

Tchobanoglous, G., F.L. Burton, and H.D. Stensel. 2003. Wastewater engineering: Treatment and reuse. 4th Ed. McGraw Hill, New York, NY.

U.S. Census Bureau. 2010. State \& county quick facts. 19 July 2010. <http://quickfacts.census. gov/qfd/states/12000.html $>$.

U.S. Department of Agriculture Economic Research Service. 2010. Consumers' response to the 2006 foodborne illness outbreak linked to spinach. Amber waves. 19 July 2010. <http:// www.ers.usda.gov/amberwaves/march10/features/ OutbreakSpinach.htm>.

Waterfacts. 2004. Water recycling. Calif. Dept. Water Resources, p. 1-8. 20 July 2010. <http://www. water.ca.gov/pubs/conservation/water_facts_no. _23_water_recycling/waterfact23.pdf $>$. 